\title{
Escorting Democracy with Local Wisdom: Depiction of Regional Election Supervision amid Pandemic
}

\author{
Kristian, Nuraliah Ali*, Karlinae D Bangas \& Supiya \\ Law Department, Faculty of Law, Universitas Palangka Raya, Indonesia
}

Received: June 27, 2021; Reviewed: July 2, 2021; Accepted: July 30, 2021

\begin{abstract}
This paper aims to describe the supervision of the Central Kalimantan regional head election during the pandemic. The problem is focused on how the description of election supervision by the Election Supervisory Agency? and what constraints are faced and their solutions in the context of local wisdom?. The research type is descriptive qualitative. Data Collecting through interviews, observation, and literature study. The data obtained were analyzed descriptively using the Mile and Huberman model. This study shows several things: First, the implementation of supervision is more on tasks outside the crucial task of Bawaslu, namely the supervision of the pandemic health protocols as an additional task burden. Second, the obstacles faced by Bawaslu start from the preparation, Voting, and post-voting. Namely: Updating and determining the voter list was constrained by the Work From Home and Large-Scale Social Restrictions policies; Procurement and distribution of logistics whose suppliers had not yet recovered from the impact of the pandemic; Some officials were reluctant and resigned because of the rapid test rules; distorted ballot papers; The officers' lack of compliance with the working mechanism that had determined. Third, The context of local wisdom in the supervision of Pilkada in Central Kalimantan, namely: Balanga, Huma Betang, Ma'mapas Lewu, Isen mulang, and Dayak Greetings: Tabe salamat lingu nalatai, Salam Sujud Karendem malempang, Adil ka' Talino bacura'mi ka' Saruga, Basengat kajubata.
\end{abstract}

Keywords: Election Supervision; Local Wisdom; Democracy; Pandemic

How to Cite: Kristian, Ali, N., Bangas, K.D., \& Supiya, (2021). Escorting Democracy with Local Wisdom: Depiction of Regional Election Supervision amid Pandemic.JPPUMA: JurnallmuPemerintahan dan Sosial Politik UMA(Journal of Governance and Political Social UMA), 9 (2): 184-195

*Corresponding author: Nuraliah Ali

ISSN 2549-1660 (Print)

E-mail: nuraliahali@law.upr.ac.id ISSN 2550-1305 (Online) 


\section{INTRODUCTION}

Holding a democratic party when the suspected Covid-19 virus is rapidly increasing is a worrying issue. The potential for growing new clusters from campaign and polling clusters (Rahmani, 2021), Issues regarding the rapid change in zone categorization, namely the green zone into the red zone (Devika et al., 2020), concerns about the capabilities of the organizers in realizing the implementation of general elections that are not only good quality elections but also ensure public safety during a pandemic (Utami, 2021). These problems certainly require serious handling. Even though a series of issues have led to the pros and cons of holding elections during a pandemic, Indonesia still holds elections on December 9,2020, based on Government Regulation instead of Law (In Indonesia called Perpu) no 2 of 2020 (Sarjan et al., 2020). As an organizing agency mandated for supervision, The General Election Supervisory Agency Office (In Indonesia called Bawaslu) certainly, bears a great responsibility in elections during a pandemic.

In addition to being responsible for ensuring that the election process takes place in a democratic, quality manner, guaranteeing the constitutional rights of the state's color, Bawaslu is also obliged to ensure strict implementation of health protocols during elections (Muhlis, 2020). Holding the democratic party during the Covid-19 pandemic does not only involve political competition between candidates but also involves competition between politics and Health. Realizing a quality election during a pandemic is not easy (Ristyawati, 2020). Series of problems, obstacles, and challenges characterize the task of Bawaslu as an Institution in charge of supervision, and Central Kalimantan's Bawaslu is no exception.

In 2020, the people of Central Kalimantan held a democratic party. The Pilkada was followed by 2 (two) candidates for governor and candidates for deputy governor, namely the pair of Ben Ibrahim S. Bahat and Ujang Iskandar and the pair of Sugianto Sabran and Edy Pratowo. The implementation of election supervision during the Covid-19 pandemic has room for problems that require more effort than general election supervision.

The study of elections during a pandemic is an attractive theme to study. Visible from the many keywords 'election and pandemic' in search engines such as google scholar. However, the majority of these studies only focused on the pros and cons of simultaneous regional elections during the pandemic (Hapsari, 2021), the dynamics of regional elections during a pandemic (Umayasari \& Kurniawan, 2020), or aspects of health protocol enforcement (Devika et al., 2020). Therefore, this paper hopes that it can provide novelty by involving local wisdom in overseeing the implementation of election supervision during the pandemic.

Local wisdom comes from the words local (certain areas) and wisdom. Local wisdom is values, norms, ethics, beliefs, customs, customary law, or special rules that contain wisdom values to regulate social life to achieve social goodness or harmony (Mariane, 2014). Local wisdom is a value that is considered good and right to last a long time, even be institutionalized. According to Article 1 number 30 of Law Number 32 of 2009 concerning the management and protection of the environment, local wisdom is the noble value that applies in the community's life to, among other things, protect and manage the environment in a sustainable manner. Prof. Nyoman Sirtha stated that local wisdom has several functions and meanings, one of which is political meaning, for example, regarding the relationship of patron and client power (Sartini, 2004).

Efforts to apply the values of local wisdom based on the characteristics of each region are the wise steps to respond to various problems regarding the implementation of supervision of regional 
head elections. Local knowledge is expected to support the achievement of a great local political situation and condition. Can develop Local values in each region positively and effectively to help overcome various post-conflict local election supervision problems. The study of the involvement of local wisdom, especially the 'Dayak' local wisdom of the Central Kalimantan as a solution to the supervisory constraints faced by the General Election Supervisory Agency Office in Central Kalimantan during elections amid a pandemic, is expected to be an offer of novelty in this paper. Therefore, this paper describes the supervision of the Central Kalimantan regional head election during the pandemic, including an overview, constraints, and solutions based on local wisdom.

\section{RESEARCH METHODS}

The research type is qualitative descriptive with a social, political, and juridical empirical approach. This research method seeks to see the facts that exist infield practice or empirical facts related to the implementation of supervision of Regional Head Election during the Covid-19 pandemic by The General Election Supervisory Agency (in Indonesia Bawaslu). The location of this research is The General Election Supervisory Agency Office of Central Kalimantan Province. Subjects in this study are resource persons, namely parties who know about the issues raised and are directly involved in these problems, namely officers at Bawaslu Central Kalimantan. Sources of legal materials include primary data and secondary data, and tertiary data. Data were collected using interviews, observations, literature studies.

Direct interviews were conducted with the Chairman of the Central Kalimantan Election Supervisory Agency and Coordinator of the Human Resources and Organizational Resources Division (Kordiv SDMO) to find out how the depiction of election supervision during the pandemic in Central Kalimantan, including legal regulations, financing, challenges, obstacles, and forms of violations that occurred. Interviews were also conducted with the Polling Station Officers (PTPS), who are traditional leaders, to obtain data on conditions of local wisdom applied in overseeing regional elections during a pandemic. Observations have started before the voting process to see how the supervision is carried out at the pre-voting stage, During Voting, and Post-Voting. A comment is carried out directly or by observing social media. Literature studies are conducted by reviewing regulatory documents related to the object of research, including written laws, government regulations, presidential regulations, Bawaslu regulations, Bawaslu Circulars, Joint Decrees related to election supervision, and Journal articles related to research.

The data analysis technique used in this research is Miles and Huberman's models, including data reduction, display, conclusion, and verification (Miles \& Huberman, 1994). The data collected through interviews, observations, and literature studies are processed by examining the answers of the informants, classifying the data based on the type, comparing the observation data with interview data, comparing the observed data with the supporting literature, and then reducing data that is not relevant to the purpose of the study. After the reduction, the data is presented in a qualitative description, which is then drawn conclusions and data verification.

\section{RESULT AND DISCUSSION The supervision of the Regional Head Election during the Covid-19 pandemic in Central Kalimantan}

Contradiction is two words that represent an overview of the monitoring of regional head elections in 2020. Satriadi (2020), Chairman of the Central 
Kalimantan Election Supervisory Agency, stated that:

"because of the pandemic the normative side of the election is slightly different, everywhere, whose name is a democratic party, it gathered a lot of people / gathered the people, but the election this timelimited and prohibited the crowd. "

Apart from the normative side, the implementation of elections during the pandemic also impacts the readiness of existing regulations.

The Covid-19 pandemic hit Indonesia in early 2020 and spread very quickly. The spread was so fast that the government issued a large-scale social restriction policy. With restrictions in all fields, the preparation of regulations related to elections in the pandemic era is not ready and seems to be all of a sudden. The previous rules demanded a response to a pandemic situation or situation manifested in the form of applicable laws. Current surveillance regulations adopt more regulatory health protocols. Satriadi said:

"the regulations that were drafted included Bawaslu regulations related to this pandemic, the adoption of health protocols became a greater proportion, such as during campaigns that gathered many people, but health protocols did not allow crowds, so the form of supervision followed the health protocol regulations."

Bawaslu certainly bears a thought responsibility because it is not only obliged to carry out its functions and responsibilities but is also required to carry out additional duties, namely Bawaslu regulations related to health protocols (Umayasari \& Kurniawan, 2020). For example, the responsibilities of Bawaslu as stated in article 97 of the Election Law, that Bawaslu must supervise the implementation of the election steps, in this case, Voting and counting of the election results, the task of Bawaslu is to handle violations related to voting and vote counting only. In the Covid-19 Pandemic, the burden of duty increases to oversee the implementation of health protocols during these stages. The applies to other steps of supervision.

The Indonesian Election Supervisory Agency reminds us of the health protocol for preventing Covid-19 in the 2020 Pilkada. If any party involved in the regional election does not comply with the health protocol, then be prepared to receive a warning to sanctions. For example, in the case that occurred in the Central Kalimantan regional election, according to Satriadi (2020), for instance, during the campaign period, candidate pairs were campaigning and causing mass crowds, so according to the applicable Bawaslu regulations, candidate pairs will be given a written warning to disperse the crowd. If the notice is not heeded within an hour, the Bawaslu officer will coordinate the related sanctions. For example, the General Election Commission issued regulations to limit campaign activities. Prohibition of conducting campaigns in the form of general meetings. Campaigns that are allowed are indoors and are limited to a maximum of 50 people. Bawaslu is in charge of overseeing the implementation and implementation of these regulations.

One of the efforts to ensure that the 2020 regional elections will continue to be carried out is by applying the rules in Article 11 of the General Election Commission Regulation of the Republic of Indonesia Number 6 of 2020 concerning the Implementation of Elections for Governors and Deputy Governors, Regents and Deputy Regents, Mayors and Deputy Mayors Simultaneously in Disaster Conditions Corona Virus Disease 2019 (Covid-19):

1) Each Election Organizer, Candidate Pairs, Campaign Team, Liaison of Candidate Pairs, as well as the parties involved in the Continuous Continuous Election must implement the health protocol for prevention and control of 
Corona Virus Disease 2019 (Covid-19) as referred to in Article 5 to Article 9 at least in the form of wearing a mask that covers the nose and mouth to the chin.

2) If there is a party violating the obligations referred to in paragraph (1), the Provincial KPU, Regency / City KPU, PPK, or PPS will give a warning to the party concerned to follow the provisions of the health protocol for prevention and control of Corona Virus Disease 2019 (Covid-19).

3 ) If the party concerned has been given a warning as referred to in paragraph (2) still does not implement the health protocol for the prevention and control of Corona Virus Disease 2019 (Covid19), the Provincial KPU, Regency/ City KPU, PPK, or PPS shall coordinate with Provincial Bawaslu, Regency/ Municipal Bawaslu, District Panwaslu, or Village Panwaslu to impose sanctions following the provisions of laws and regulations.

Each step of the regional election, all organizers, regional heads, regional head candidates, supervisors, and state security officials can adjust to the Covid-19 election mechanism and health protocol and actively create a conducive situation. The enforcement of the health protocol discipline is prioritized considering that the election activity, especially the campaign, is a stage that involves the masses. That is a big challenge to carry out simultaneous regional elections in 2020 during this Covid-19 pandemic. Due to several violations regarding the enforcement of the Health protocol discipline, there are still many.

\section{Constraints of Supervising Regional Election during the Pandemic and the local wisdom solutions}

Constraints. The implementation of the Pilkada amid the trend of increasing the number of positive cases in the country has raised pros and cons. However, various reasons are the basis for why the Pilkada must still be carried out during a pandemic, namely:

First, implementing the law, postponed to December 9,2020, is stated in Perppu Number 2 of 2020 as a legal basis (Hasibuan, 2020).

Second, no one can confirm when the pandemic will end. If you continue to delay the implementation of the Pilkada, new problems will arise, such as the vacant position of regional leaders and the implementation of overlapping regulations (Maharani \& Efriza, 2021). The term of office of each regional leader has been determined in Law Number 22 of 2014 concerning the Election of Governors, Regents, and Mayors; those elections are held every five years, if not carried out according to schedule, there will be new problems that arise related to the appointment of regional heads.

Third, the constitutional rights regarding Voting and being elected, this reason returns to the uncertainty of when the Covid-19 pandemic will end (Kennedy \& Suhendarto, 2020). It also has implications for chaotic budget management; if postpone the elections until the past 2020, the election funds budgeted for the current year cannot be used because the fiscal year has passed. These reasons are reinforced by collaborative steps taken by the KPU, DPR, Government, and the person in charge of the Task Force for the acceleration of Covid-19 to synergize the success of the 2020 Pilkada Simultaneously.

The holding of simultaneous regional head elections is nothing new in a democratic country like Indonesia. However, holding a 5-yearly democratic party simultaneously during a pandemic is not an easy matter. The challenges and obstacles in holding elections are becoming more complex and not easy. The implementation of election supervision becomes harder for the Bawaslu because, in addition to guaranteeing the quality of elections, they require strictly 
implementing health protocols to maintain public safety. In the supervision activity by Bawaslu during a pandemic, there are several obstacles to be faced. There are several obstacles to the implementation of supervision by Bawaslu in the regional elections in Central Kalimantan, including:

a. Constraints at the Preparation Stage

The Election Law assigns duties, powers, and obligations to Provincial Bawaslu as stipulated in Article 97 to Article 100. The forms of constraints in the preparation stage include:

1) Updating of voter data, determination of provisional voter lists and final voter lists

Obstacles in the early stages of the supervisory task have started from the updating process of voter data, the stipulation of provisional voter lists, and the final voter lists. Due to social restrictions during the pandemic, these activities are constrained by the interaction that requires work from home (WFH). Constraints in maintaining the accuracy and validity of voter data due to disruption of electronic KTP services during the pandemic, the high movement or mobilization of people between regions because companies, offices, shops were closed during the pandemic, and the large number of migrant workers returning to Indonesia

The task of the Bawaslu ranks must ensure that eligible voters must enter the voter list, and those who do not meet the requirements must leave the voter list. That is the main point of the voter (Isnaini, 2018), but during the Covid 19 pandemic, the room for movement and interaction of officers was limited. This results in potential procedural mismatches, such as Officers not conducting house-to-house Coklit, Officers not posting stickers, etc., which can cause the Voters' list to be inaccurate, out-of-date, inconsistent.

2) Procurement and distribution of logistics
Supervision Logistics distribution is a very vulnerable activity. It is prone to violation or abuse. In Central Kalimantan, supervision activity related to the distribution of ballots was initially for tri zones. Still, it later changed to five distribution zones, according to the ballot distribution schedule set by the KPU of Central Kalimantan Province. The five ballot distribution zones include: Zone 1: East Barito, South Barito, North Barito and Murung Raya Regencies; Zone 2: Kotawaringin Timur and Seruyan Districts; Zone 3: Kapuas District, Pulang Pisau and Kota Palangka Raya; Zone 4: Gunung Mas Regency; Zone 5: Katingan, West Kotawaringin, Lamandau and Sukamara districts.

According to Tity Yukrisna (2020), Coordinator of the Human Resources and Organizational Resources Division said that the focus of supervision of the Central Kalimantan Provincial Bawaslu in the distribution of ballots is supervision in terms of security in the implementation of distribution, timeliness of distribution, suitability of types, quantities and targets, compliance with distribution procedures, storage security, and application of health protocols and prevention of the spread of Covid-19. The obstacles faced are related to the procurement and distribution of logistics, namely the industrial sector that supports the procurement of goods and services for logistics purposes which has not fully recovered from the impact of the Covid-19 pandemic. The regulations for implementing mobilization from and outside the region must use a Covid-19 free certificate as a rapid test and assignment letter, which is an obstacle in this process.

3) The Health and safety of officers Aspects

In regional head elections, Bawaslu must ensure that the main tasks run well, oversee the implementation of health protocols for citizens, and pay attention to the health protocols of their members. In the RegulationRegulation of the General Election Supervisory Agency (Perbawaslu) 
number 4 of 2020 , in article 3 point $b$ that the ranks of the provincial Bawaslu, Regency/ City Bawaslu, District/ City Panwaslu, Village Panwaslu, and TPS Supervisors before and after carrying out the supervision must carry out a rapid test and medical examination. Based on the results of an interview with the head of the Central Kalimantan Bawaslu, Satriadi stated that regarding the fast test rules for supervisory officers, there were obstacles, namely that there were some officers who did not want to carry out rapid tests for reasons of fear or their area had no cases of Covid or the green zone. There are even some who choose to resign. Furthermore, according to Satriadi, the provincial Bawaslu had formed supervisors at all levels before the pandemic spread widely in Indonesia and carried out socialization related to the notification of health protocol regulations such as rapid testing from an early age. So that all officers are obliged to follow the existing rules, not interpret the applicable rules

Constraint in the safety aspect is difficulty in providing personal protective equipment (PPE) for Bawaslu members. The provision of PPE for officers through an auction mechanism is relatively short in time. The need for PPE for officers in Central Kalimantan is quite a lot because all officers at every level must obtain PPE. Meanwhile, the need for masks and PPE in large quantities is limited and scarce, so the demand for procurement must be fast, and in large amounts is certainly an obstacle in itself. Satriadi stated that the number of TPS in Central Kalimantan is 6045. There are 136 sub-district ranks. The supervisor is tri sub-districts, one person in village supervisors and one person per person TPS. With many officers who received PPE and endurance-boosting multivitamins, the supply and availability of PPE were very difficult and much sought after.

4) Campaign Process

Concurrent regional election campaign activities in 2020 were held from
September 26 to December 5, 2020; there are several adjustments to prevent Covid19. The culture in Indonesia, where campaigns are synonymous with mass mobilization (Hutapea, 2015), however, large-scale social distancing policies regulate physical or social distancing. Furthermore, the KPU has stipulated General Election Commission Regulations no. 13 of 2020, revised the previous regulations. Article 58 in the new RegulationRegulation states that candidates in the 2020 regional elections must prioritize social and online campaign activities. Online campaigns through social media or online media are difficult to control for election administrators, including election supervisors. Monitoring disinformation, especially hoaxes and fake news, will dominate virtual public spaces, including monitoring and curbing virtual campaigns in quiet times.

Suppose the candidate pair does not want to campaign through social media and online media. In that case, they allow to choose face-to-face meetings with a maximum number of participants and implement health protocols to prevent the spread of Covid-19. In article 88C, the KPU strictly prohibits campaign teams from carrying out activities that usually gather large numbers of people, such as general meetings, cultural activities such as performing arts or music concerts, sports activities, competitions, social activities, or commemoration of political party birthdays.

Campaign supervision in Central Kalimantan focused on monitoring health protocols. The obstacles faced when pairs of candidates carry out a campaign in the form of "blusukan" to the market, while the market itself is difficult for the crowd to avoid. Monitoring officers in the field have issued many warnings to implement health protocols such as wearing masks, maintaining distance, and washing hands. The form of campaign supervision in Central Kalimantan is more not the core/ 
main task of Bawaslu. Instead, supervision activity is more related to the addition of charge to the supervisory task load, namely the health protocols. b. Constraints on the Stages of the Voting
Day

Voting is the culmination stage of a general election. Voting according to the provisions of Law no. 10 of 2016 held at the TPS. Supervision of Voting is regulated in article 31 Perbawaslu no 4 of 2020. The obstacles to overseeing Voting are more on matters of a non-technical nature but on monitoring the implementation of health protocols. Crucial aspects that become the focus of supervision related to Voting include the potential for violations of voter mobilization, officer non-neutrality, intimidation, voters voted more than once, logistical shortages, and violations related to the closing time of polling stations. However, supervision dominates with wearing mask matter in the field, regulating queuing distances outside TPS, measuring body temperature, etc.

The obstacle or problem in monitoring voting in Central Kalimantan, for example, is that officers are obliged to ensure the implementation of health protocols at polling stations, such as those who wish to vote for Voting are required to wear masks. However, some voters came to the polling station without covers because the area is a green zone, there is no Covid19 in the area. The officer explained the mandatory rules for implementing health protocols and distributing masks to those who did not use masks in TPS, not to mention the provision and installation of gloves, so it took a little longer for individuals to vote.

c. Constraints at the Post-Voting Stages

After voting, the next important step is for Bawaslu officers to supervise the vote-counting process at the polling stations. Officers count the votes after the polling stations are closed for voters. Supervision of vote counting follows KPU regulatory procedures. In addition,
Bawaslu stated that polling station supervisors must ensure the data's suitability, accuracy, and correctness on vote counting results. The Election Supervisors are fully responsible for ensuring that all processes on polling day and vote counting are honest, fair, and transparent (Jurdi, 2018). Supervisors are responsible for preventing potential vulnerabilities, processing, and following up on violations to create democratic and quality simultaneous elections.

Referring to the Bawaslu guidebook on the details of supervisory duties after voting, the obstacles to supervision by Central Kalimantan Bawaslu officers after Voting are problems related to missing or mixed ballot papers, lack of obedience to the voting organizers (KPPS) with the working mechanism, officers do not ask for cards e-Ktp on the grounds of having C6. According to Satriadi:

"If the officer did not check for electronic KTP, it is vulnerable. That is what we regret. However, the implementation of Voting in Central Kalimantan is still running smoothly, and there has been no recommendation for re-voting ".

Regarding the violation report by one of the pairs of candidates, contained in the copy of Central Kalimantan Bawaslu's preliminary decision number: 01 / Reg / L / TSM-PG / 21.00 / XI / 2020, that the reported party as one of the candidates' pairs was reported to have committed an election administration violation (TSM) namely promising and giving money or other materials to influence election organizers and voters, as for the decision to be followed up with an examination hearing. Furthermore, the results of the decision related to the violation are contained in the Bawaslu Decision, Number: $\quad 01 / \mathrm{Teg} / \mathrm{L} / \mathrm{TSM}$ $\mathrm{PG} / 21.00 / \mathrm{XI} / 2020$, states that the reported party has not been legally and convincingly proven, promised, provided money, or other materials. to influence 
election organizers or voters of violations in a structured, systematic and massive manner.

Local Wisdom Solution. Central Kalimantan Bawaslu, one of the institutions responsible for regional election supervision in Central Kalimantan, needs to think about strategic steps to ensure the implementation of elections that are not only of high quality but also capable of maintaining the safety of people's lives in Central Kalimantan. Realizing a quality Pilkada during a pandemic is not easy; a series of problems, obstacles, and challenges characterize the task of Bawaslu as the person in charge of supervision. To respond to an issue concerning the practice of implementing simultaneous regional elections, applying local wisdom values based on the characteristics of the Central Kalimantan region is one option.

The values of local wisdom that raised in response to issues related to the supervision of regional elections during a pandemic in Central Kalimantan are:

\section{Balanga}

In 2020 in Central Kalimantan, the Provincial General Election Commission has brought "Balanga Persatuan," abbreviated as "BaPer," as the mascot of the 2020 Pilkada. Balanga is a Dayak ceramic jar usually used as a traditional item at proposing events and a place to serve food for the ancestors; this jar has a sacred noble value for the Dayak people (Sentosa \& Suprapti, 2020). Balanga is a symbol of unity, harmony, togetherness, and cooperation in advancing Central Kalimantan. Bawaslu internalizes the value of Balanga local wisdom in carrying out its duties and functions to make the regional elections in Central Kalimantan successful even during a pandemic. The community has been invited to supervise the Pilkada jointly. Satriadi, Head of Central Kalimantan Bawaslu revealed that:

"Surely, each pair of candidates has their success team. We can monitor their strategies and movements, so that there are no loopholes for committing violations. Therefore, the participation of the community is necessary to monitor violations according to the rules in the election legislation."

Based on observations made before the last Pilkada, many banners containing an invitation to supervise the Pilkada were seen. In addition to inviting the wider community to play an active role in overseeing the Pilkada, both direct and indirect supervision, Bawaslu also seeks to encourage the involvement of traditional leaders and traditional institutions in the election monitoring process.

The existence and role of Adat institutions in Central Kalimantan have a strong value in community life. The participation of traditional institutions in democratic events in Central Kalimantan will create political stability and suppress the potential for chaos during the Pilkada. Various conventional leaders of the Dayak Adat Council, damang, and mantir have declared peace to support the elections to run well, peacefully, safely, and conductively. For example, in maintaining the integrity of the Republic of Indonesia in Bumi Tambun B Sungai, Bumi Pancasila, especially, ahead of the regional elections. Dewan Adat Dayak (DAD) of Central Kalimantan Province The council and the management share a joint commitment, which includes: First, Central Kalimantan DAD Participates in the success of a Safe, Peaceful and Healthy Regional Election and invite the public to exercise their voting rights, not to become Golput. Second, the Central Kalimantan DAD also maintains the peace and conduciveness of Community and Community Service in the Central Kalimantan Province. Third, DAD Central Kalimantan rejects all anarchist acts of any kind that can disturb the peace in Central Kalimantan, which is not following the philosophy of "Huma Betang" and "Belom Bahadat". Fourth, Central Kalimantan DAD rejects anyone / any figure who comes to Central Kalimantan to disturb peace and 
tranquility. Fifth, support law enforcement against any violation of the Covid-19 health protocol.

\section{Huma Betang}

Betang is a permanent residence for several generations, built in the village by several families who still have blood ties/descendants or houses that accommodate many families in that building (Usop, 2011). Philosophically, Huma Betang can also be interpreted as a cultural embodiment of living together under one roof, cooperation, mutual understanding under the auspices of clear customary law. Some of the constructions of Huma Betang's cultural values are: a) Hampahari, as brotherhood and togetherness in life in Betang, b) Handep, is mutual help, pandohop, (help), mutual mandohop (helping), c) Below Bahadat, civilized life and have ethics, namely respecting the customs that apply in the territory of the orthodox community, d) Hapakat Kula, mutual agreement regarding common interests must be decided together through consensus (Rostiana et al, 2020).

Huma Betang's philosophy is one of the philosophies of the Central Kalimantan Dayak community with the concept of being free to lead. Huma Betang philosophy highly upholds peace and non-violence as well as a high tolerance life. In the 2020 Pilkada, Bawaslu and other Pilkada organizers always remind the public to put this philosophy forward in the elections in Central Kalimantan, both in the process and in solving problems that arise. The synergy between the community and the provincial or district/city Bawaslu under supervision will certainly be a great force to keep the Pilkada away from various violations and fraud.

\section{Ma'mapas Lewu}

Ma'mapas Lewu is a routine or annual ritual carried out by the Central Kalimantan Dayak Customary Council (In Indonesia called DAD). Ma'mapas Lewu's philosophy is to rid the area of bad influences
(Chilwanto et al., 2021). Ma'arak Sahur as an expression of gratitude and gratitude to the ancestors of Central Kalimantan who have guarded and provided favors, health, and strength as well as protection for the people who live on Bumi Tambun Bungai (Biro Administrasi Pimpinan Sekretariat Daerah Provinsi Kalimantan Tengah, 2020). Regarding the 2020 Pilkada, the Ma'mapas Lewu ritual is also carried out for tri days, taking place in Betang Hapakat and around the city of Palangka Raya to request the realization of a safe and conducive Pilkada in Central Kalimantan.

\section{Isen Mulang}

Isen mulang is an expression from Tjilik Riwut, which is the motto of the strength of the people of Central Kalimantan (Sentosa \& Suprapti, 2020). The phrase means "My Message is Don't Give Up," which is currently the motivation and strength of the people of Central Kalimantan. Isen Mulang's symbol describes the value of the philosophy of toughness and orientation on achievement/success. The value of local wisdom behind this means that it is very important for the success of the direct election in Central Kalimantan, namely that all parties, especially the supervisory officers, must work hard, must try, must sacrifice for the benefit of the community. A successful election during a pandemic requires great effort and struggle and an unyielding attitude to the challenges that arise both at the preparation, implementation, and post-voting stages.

\section{Dayak Greetings}

Tabe salamat lingu nalatai, Salam Sujud Karendem malempang, Adil ka' Talino bacura'mi ka' Saruga, Basengat kajubata is a traditional Dayak greeting. The greeting means greetings of peace and prosperity always, welcome to meet you in a happy state, fair to fellow human beings, reflecting heaven, the breath of life comes from God The greeting is usually said as an opening 
greeting at every event organized by various elements of society, including the government. The meaning of this local wisdom is very positive to overcome various problems related to the election. Prioritizing peace when there is a clash during the election, upholding justice for the settlement of election disputes, having concern for the safety and welfare of others above the interests of the group, and always realizing the importance of building communication with God Almighty, Allah SWT, in the hope that safety, peace, and prosperity will always be given all the efforts made include efforts to succeed in the supervision of peaceful elections during a pandemic.

\section{CONCLUSION}

The implementation of supervision by Bawaslu is more on matters beyond the crucial task of Bawaslu itself, namely monitoring the performance of health protocols as an additional task burden. The obstacles faced by the Bawaslu started from the preparation, Voting, and post-voting, such as updating and establishing the list of voters that WFH and PSBB constrained, procurement and distribution of logistics whose suppliers had not yet recovered from the impact of the pandemic, some officers were reluctant to carry out rapid tests and some even resignation, floppy ballot papers, and the lack of compliance of KPPS with work mechanisms. The context of local wisdom in the supervision of Pilkada in Central Kalimantan, namely: Balanga, Huma Betang, Ma'mapas Lewu, Isen mulang, Dayak Greetings: Tabe salamat lingu nalatai, Salam Sujud Karendem malempang, Adil ka' Talino bacura'mi ka' Saruga, Basengat kajubata REFERENCES

Biro Administrasi Pimpinan Sekretariat Daerah Provinsi Kalimantan Tengah. (2020). Asisten I Wakili Gubernur Kalteng Hadiri Kegiatan Ritual Ma'mapas Lewu Tahun 2020. Https://Setda.Kalteng.Go.Id/Publikasi/Detai l/Asisten-i-Wakili-Gubernur-Kalteng-Hadiri-
Kegiatan-Ritual-Mamapas-Lewu-Tahun2020.Acceed on January 2020

Chilwanto, E., Safna, S., Mutiara, M., Rahmad, G., Offeny, 0., \& Saefulloh, A. (2021). Upacara Ma'Mapas Lewu (Studi Kasus di Kota Kasongan Kalimantan Tengah). Jurnal Kewarganegaraan, 5(2), 374-354.

Devika, M., Mulyono, G. P., \& Nahuddin, Y. E. (2020). Penegakan Protokol Kesehatan dalam Penyelenggaraan Pilkada Serentak di Tengah Pandemi Covid-19. Conference on Law and Social Studies., 1(1), 1-15.

Hapsari, D. A. (2021). Wacana Pro Kontra Pilkada Serentak di Masa Pandemi Covid-19 pada Pemberitaan Online. Imajeri: Jurnal Pendidikan Bahasa Dan Sastra Indonesia, 3(2), 140-148.

Hasibuan, R. P. P. M. (2020). Urgensitas Perppu Pilkada Di Kala Wabah Pandemi Covid-19. ADALAH, 4(1).

Hutapea, B. (2015). Dinamika hukum pemilihan kepala daerah di Indonesia. Jurnal Rechts Vinding: Media Pembinaan Hukum Nasional, 4(1), 1-20.

Isnaini, H. (2018). Kedudukan, Tugas Dan Kewenangan Bawaslu Menurut UndangUndang Nomor 15 Tahun 2011 Tentang Penyelenggara Pemilihan Umum Dan UndangUndang Nomor 7 Tahun 2017 Tentang Pemilihan Umum. Yogyakarta: Universitas Islam Indonesia (Skripsi).

Jurdi, F. (2018). Pengantar Hukum Pemilihan Umum. Kencana.

Kennedy, R., \& Suhendarto, B. P. (2020). Diskursus Hukum: Alternatif Pola Pengisian Jabatan Kepala Daerah di Masa Pandemi Covid-19. Jurnal Pembangunan Hukum Indonesia, 2(2), 188-204.

Maharani, A., \& Efriza. (2021). Manajemen strategis pilkada serentak 2020: belajar dari suksesnya pemilu korea selatan di tengah pandemi covid-19 (strategic management of local election 2020: learning from the success of south korea election under the covid-19). Jurnal Sosial Dan Humaniora, 5(10), 199-214.

Mariane. (2014). Kearifan Lokal Masyarakat Hutan Adat. Rajawali Pres.

Miles, M. B., \& Huberman, A. M. (1994). Qualitative data analysis: An Expanded Sourcebook (Second). Sage.

Muhlis, M. (2020). Polemik Pilkada 2020 Di Masa Pandemi Covid-19: Antara Demokrasi Dan Oligarki. Ganaya: Jurnal Ilmu Sosial Dan Humaniora, 4(1), 116-141.

Peraturan Komisi Pemilihan Umum Republik Indonesia Nomor 6 Tahun 2020 Tentang Pelaksanaan Pemilihan Gubernur dan Wakil Gurbenur, Bupati dan Wakil Bupati, Wali Kota dan Wakil Wali Kota Serentak Lanjutan 
Dalam Kondisi Bencana Nonalam Corona Virus Disease 2019 (Covid-19).

Peraturan Pemerintah Pengganti Undang-Undang Republik Indonesia Nomor 2 Tahun 2020 Tentang Perubahan Ketiga Atas UndangUndang Nomor 1 Tahun 2015 Tentang Penetapan Peraturan Pemerintah Pengganti Undang-Undang Nomor 1 Tahun 2014 Tentang Pemilihan Gubernur, Bupati, Dan Walikota Menjadi UndangUndangRahmani, A. A. N. (2021). Potensi Masalah Pilkada Serentak 2020 dan Kekhawatiran Masyarakat Pemilih Muda. KEMUDI: Jurnal Ilmu Pemerintahan, 5(2), 167-178.

Ristyawati, A. (2020). Efektivitas Pelaksanaan Pilkada Serentak 2020 Pada Masa Pandemi Darurat Covid-19 di Indonesia. CREPIDO, 2(2), 85-96.

Rostiana, H., Nurbani, S., \& Riswanto, D. (2020). Nilai-Nilai Filosofis Huma Betang Suku Dayak Kalimantan. Jurnal Budaya Nusantara, 3(2), 118-125.

Sarjan, S., Mulya, K. al K., \& Chadijah, S. (2020). Problematika Dan Teknis Penyelengaraan Pemilihan Kepala Daerah Pada Masa Pandemi CoviD 19. Rechtsregel: Jurnal Ilmu Hukum, 3(1), 59-76.

Sartini, S. (2004). Menggali kearifan lokal Nusantara: Sebuah kajian filsafati. Jurnal Filsafat, 14(2), 111-120.

Sentosa, A., \& Suprapti, W. (2020). Pendidikan Politik Bagi Siswa Kelas XII Berbasis Kearifan Lokal Di Kecamatan Pahandut Kota Palangka Raya. Anterior Jurnal, 20(1), 55-63.
Umayasari, U., \& Kurniawan, R. C. (2020). Dinamika Pilkada di Tengah Pandemi dalam Memenuhi Amanat Konstitusi. Dinamika Pilkada Di Tengah Pandemi Dalam Memenuhi Amanat Konstitusi, 14(02), 69-79.

Undang-Undang Republik Indonesia Nomor 10 Tahun 2016 Tentang Perubahan Kedua Atas Undang-Undang Nomor 1 Tahun 2015 Tentang Penetapan Peraturan Pemerintah Pengganti UndangUndang Nomor 1 Tahun 2014 Tentang Pemilihan Gubernur, Bupati, Dan Walikota Menjadi Undang-Undang

Undang-Undang Republik Indonesia Nomor 8 Tahun 2015 Tentang Perubahan Atas UndangUndang Nomor 1 Tahun 2015 Tentang Penetapan Peraturan Pemerintah Pengganti Undang-Undang Pemilihan Gubernur, Bupati, Dan Walikota Menjadi UndangUndang

Usop, T. B. (2011). Kearifan lokal dalam arsitektur kalimantan tengah yang berkesinambungan. Jurnal Perspektif Arsitektur, 6(1), 25-32.

Utami, D. K. S. (2021). Penyelenggaraan Pemilihan Kepala Daerah Serentak Tahun 2020 di Tengah Pandemi Covid-19 Berdasarkan Undang-undang Nomor 6 Tahun 2020. Wasia: Jurnal Pemilu Dan Demokrasi, 1(1), 13-26.

Yukrisna, T. (2020). Bawaslu Kalimantan Tengah Bentuk 5 Zona Pengawasan Pendistribusian Surat Suara. Https://Kalteng.Bawaslu.Go.Id/Informations /View/Bawaslu-Kalimantan-Tengah-Bentuk5-Zona-Pengawasan-Pendistribusian-SuratSuara.Html. Tanggal 20 Februari 2021. 